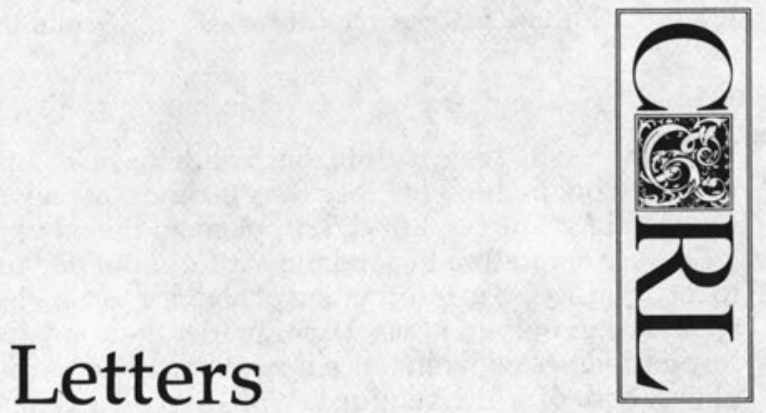

To the Editor:

Thank you especially for publishing the Stephen K. Stoan article, "Research and Library Skills: An Analysis and Interpretation" in the March 1984 issue.

This excellent article says it all, by cutting to the center of the situation to expose reality and define a problem which has been troublesome to so many for so long.

\title{
GAIL HITT
}

Director of Institutional Research, Fordham University

\section{To the Editor:}

Stephen Stoan's article "Research and Library Skills: An Analysis and Interpretation" was helpful in clarifying the sources of misunderstanding between librarians and instructors. It seemed to me, however, that if one took his explanation of the research process to its logical end, one would conclude that bibliographic instruction is, as it is currently structured, totally irrelevant, and indeed useless. Why bother teaching library skills when most primary sources exist outside the library and secondary sources can be found through citations, contacts with colleagues, etc.? I do not disagree that most scholars do research this way, but I do disagree with the notion, attributed to instructors, that library assignments have no educational value. The current dependence upon textbooks and assigned readings is dangerously narrow and has created a class of citizens who have little idea of how to pursue independent study. By independent study I do not mean scholarship, but information seeking for limited and short-term purposes related to work and everyday life. Access tools and tertiary reference tools can be extremely helpful for those needs and not to introduce students to them limits their horizons. That we have become an information society has become a cliche; nonetheless, there is truth to this statement. Opening students' eyes to the richness of libraries as an information source (albeit only one) is a valid educational objective if we believe that the ability to gain access to and use information is important.

By overemphasizing the scholarly research process Mr. Stoan gives short shrift to the information needs of undergraduates. Like it or not, most freshman composition courses require a term paper based on library research. Surely the strategy these students will follow will be radically different than the scholarly research process. Not having personal files, professional colleagues, or knowing the function of footnotes, they are in most cases going to have to depend on access tools. To equate library skills with research is appropriate for this group of students. That librarians tend to equate library skills with research is in part due to the heavy use undergraduates make of reference services. Analyses of circulation statistics that show that graduate students and faculty are the heaviest library users are misleading in this respect.

Much evidence supports the observation that faculty do not use indexes and other access tools, but I would contend that many of them could actually benefit from a systematic search of the indexes in their fields. Despite the efficiency of professional networks, my guess is that many faculty are probably not on top of the literature in their fields. Teaching demands, the sheer quantity of work being published, and the increasing trend toward interdisciplinary research make this all but impossible. Probably many deliberately narrow their focus to a few key journals, attend a few professional meetings, cultivate friendships 
with others who seem to be in touch with the field, and trust that they have not overlooked a major work in the field. Searching the indexes may not be the only way of gaining access to secondary sources, but can supplement the other means scholars use.

Because of our training and the nature of our day-to-day reference work, librarians tend to focus on access to information or sources and are less aware of primary sources than we should be; however, in academic libraries there is a trend toward combining book selection responsibilities with reference work and a trend toward advanced study in academic disciplines, both of which require knowledge of the primary sources. These trends should increase our understanding of the scholarly needs of the faculty, but improving relationships with faculty also depends upon the faculty's increasing their understanding of the mission and goals of libraries, and this is a much tougher problem. Mr. Stoan fails to mention that often scholars look at the library from a narrow and self-serving point of view. Yes, microfilms are difficult to use, but discovering that an important article has been razored out of a periodical is even more frustrating. Scholars must be educated to understand the problems most libraries face and the trade-offs made to solve these problems.

KAREN KINNEY

Head, General Reference Division, New York University

To the Editor:

The publication of "Tenured Librarians in Large University Libraries," by Karen F. Smith, et. al. [March 1984] addresses a number of important and interesting research questions; unfortunately, the "research" is so poorly done, that the results have little meaning.

The sample is never shown to be a valid representation of academic librarians or a subgroup of academic librarians and thus, is not generalizable (especially with a $52 \%$ response rate), a copy of the questionnaire is not available as an appendix for the reader, key definitions (such as what exactly constitutes an "article") are not provided, huge assumptions are made as to participants' interpretation of questions, no explanations of the limitations and weaknesses of the study or its findings are offered to the reader, statistical techniques are poorly utilized, and there are no indications of the reliability or validity of the data reported.

Space does not permit a thorough review of the research, but one of the key questions asked was "How productive are librarians before and after tenure?" The results are based on a self-administered questionnaire where "librarians were asked to indicate their productivity," before and after tenure. Without pre-tests and external validation, selfreported data is suspect and self-reported data related to personal productivity is cause for even more suspicion; one is not surprised (given the research design) to find that the sample of tenured librarians believed that they had not changed their "productivity" since being tenured.

Research questions such as this deserve better than survey research. To adequately address such questions, longitudinal data that covers an individual's "productivity" prior to and after tenure would be necessary, with some outside verification included to insure the validity of the data. However, such research calls for knowledge of research techniques other than survey questionnaires.

One is left mystified with the authors' statement that "the findings . . . do provide base data which individuals and library personnel committees can use for comparative purposes." To what is the data to be compared against? For what purposes? Since there are no indicators of the reliability of the data, and the validity is clearly suspect, why bother comparing it to anything?

Unfortunately, this type of research simply reinforces the notion to other academic librarians that such articles are "good research" and worse, someone else, with even less knowledge conducting and interpreting research, will use it for an inappropriate reason and to justify or support a position, decision, or activity, for which it is either invalid or inappropriate. 
As pointed out later in this issue by Stoan, academic librarians typically have little background and training in conducting research since they "seldom do research" (p. 105). Thus, editorial staff of professional journals have a responsibility to insure publication of only quality research (if the article is intended to be a research piece) and provide additional training and education (if necessary) to writers who are unfamiliar with the administration and reporting of research; otherwise, such articles should be rejected out-of-hand. Printing "research" papers such as this only encourages the profession's acceptance of sloppy and undergraduate quality research and confounds the notion of what is "acceptable" as research in a scholarly journal such as C\&RL.

While the authors of the article can be excused if they have never had adequate training and background in conducting research and developing research designs that fit the objectives of a specific problem, the editors and editorial board of C\&RL have no excuses. The article should never have been published in its current condition without major reworking, clarification, and explanation. Such is the responsibility of the editorial staff of the journal.

The recent proliferation of "research" under the guise of poorly designed and administered survey research needs much greater editorial control than the editors of this journal (as well as a number of other scholarly journals in our field) appear to either want to provide or are able to provide. Editorial work is time-consuming and painful; yet the quality of C\&RL depends on such efforts. I for one look forward to higher quality research and increased editorial control over the reporting of such "research" in future issues of C\&RL.

CHARLES R. MCCLURE

Associate Professor, University of Oklahoma

\section{To the Editor:}

In response to the article in the November 1983 issue of College \& Research Libraries entitled "The ACRL Standards for Faculty Status: Panacea or Placebo," ' by John N. DePew, the Council of Chief Librarians of the City University of New York wishes to go on record as strongly reaffirming the concept of faculty status for librarians. At CUNY librarians have been accorded both faculty rank and status since 1965, and have been recognized as peers in the educational process by their colleagues who teach in the college classroom.

Our position on this issue is as follows:

The libraries of the City University are organized as instructional departments within their respective colleges, and have been so designated since 1938/39 when the Board of Higher Education evolved the departmental structure, the Personnel and Budget Committee system, and the tenure and promotional procedures characteristic of CUNY today. And, since 1965, after a study by an outstanding consultant, librarians employed in these departments have held the ranks and titles of the faculty in these institutions, except that they work a standard 35-hour week and have half the annual leave allowance of the classroom faculty. They are recruited, hired and evaluated in the same manner as other faculty, according to standards, background, and experience appropriate to their work and the needs of the library. Because of these standards and the evaluation process, the University has been able to attract an unusually well qualified group that has lent distinction to our college libraries as educational institutions.

\section{A. Why Faculty Rank for Academic Librarians?}

A statement prepared by a committee of the Association of American Colleges, Association of College and Research Libraries and the American Association of University Professors (1973) said in part,

"All members of the academic community are likely to become increasingly dependent on skilled professional guidance in the acquisition and use of library resources as the forms and numbers of these resources multiply, bibliographical systems become more complicated, and library technology grows increasingly sophisticated. The librarian who provides such guidance plays a major role in the learning process."

Teaching, research, and the promotion of intellectual pursuits are the hallmarks of the university, and the librarians are a unique and indispensable part of this process. Academic 
recognition seems quite logical for the following reasons:

1. Librarians teach and instruct. The special mission of the library is to equip students with the skills in information gathering that they will use throughout their careers and which should be part of their basic education. This instruction can take place in credit courses in library skills and sources of information, or in course-related lectures and seminars. Individual consultation with librarians, geared to the student's individual needs, is still the most frequently used approach to student use of the library. At City University, with its numbers of non-traditional students who come seeking a better life through education, librarians can help in the battle against high attrition rates by arming the student with the proper intellectual weapons to see him through. What do librarians profess? Putting knowledge to work.

2. Librarians are intimately involved in the research process on the college campus. They seek to establish a research competence that includes knowledge of the principles of systematic research, the use of general and specific research sources, the ability to define a problem, and to limit, select, and evaluate material most relevant to it.

The exponential proliferation of publications and the oft-noted increasing complexity of bibliographic tools have created the need for library personnel of widely differing experiences and expertise. Library technology, advancing with amazing speed, is creating new means of approaching the organization, manipulation, and management of information. It is not difficult to foresee a time when no research of any consequence will be able to be conducted without the assistance and guidance of an experienced and knowledgeable search strategist.

3. The Library is best capable of contributing to the educational mission and tone of the college when it is recognized as a faculty department. As members of a college faculty librarians are involved in what is going on and can exercise a positive influence on the direction of events. Participation is one of the earmarks of a high quality institution. Librarians at City University have occupied important positions in faculty bodies, such as Chairman of the Curriculum Committee (N.Y.C. Community College), Secretary of the Faculty (Baruch) and the Liberal Arts Personnel and Budget Committee (Baruch), and member of the top-level "Committee of Six" (Queens). Some have advanced to the position of Dean: Bronx Community College, Staten Island, and Borough of Manhattan. The Acting President of Bronx Community College was a member of the Library Department.

B. Faculty Status and Faculty Rank. Where? How?

The Association of College and Research Libraries (ACRL) has long sought to provide proper standards for American college libraries so that they might best serve their constituencies. The Standards for College Libraries, promulgated on July 3, 1975, attempt to "describe a realistic set of conditions which, if fulfilled, will provide an adequate library program in a college." The standards are discussed under eight headings. Standard 4 deals with staff and states, in part:

"The librarians of a college comprise the faculty of the library and should organize and administer themselves as any other departmental faculty in the college. The status, responsibilities, perquisites, and governance of the library faculty shall be fully recognized and supported by the parent institution, and it shall function in accord with the ACRL "Standards for Faculty Status for College and University Librarians"."

No precise up-to-date record exists at the present time as to the exact extent and nature of the faculty association of librarians on American college campuses. However, several special surveys and studies in recent years shed some light on current practice. The most ambitious of these was undertaken in 1976 by ACRL to determine how many institutions regarded their librarians as faculty. Its salary survey included the question, "using the definition of faculty status in your institution, do librarians have faculty status"'? Seventy-five percent of the 1200 institutions responding answered yes. (Ten years before, in 1966, only fifty percent had replied in the affirmative).

In the matter of the granting of faculty ranks and titles, LACUNY (Library Association of the City University) has garnered a list of over 100 colleges which provide such perquisites to their librarians. Among the larger institutions one finds the University of Georgia, University of Illinois, University of Idaho, Iowa State University, University of Oregon. Smaller institutions are represented by Skidmore College, Connecticut College, University of Wyoming, Kean College, Simpson College. An older study of replies from 183 State colleges and universities in 1967 showed that $65 \%$ of them accorded their librarians academic ranks. (CERL 29:381-86 Sept. 1968) Here were included Colorado State University, Texas A. and M., University of Houston, Wisconsin State, Newark State University, etc. One of the more recent indications of faculty rank and status is a survey of its membership taken by the Association of Research Libraries in December 1979. Ninety-one of its one hundred thirteen members responded. Over $70 \%$ designate their librarians as academic ( 27 reported full academic status, 25 indi- 


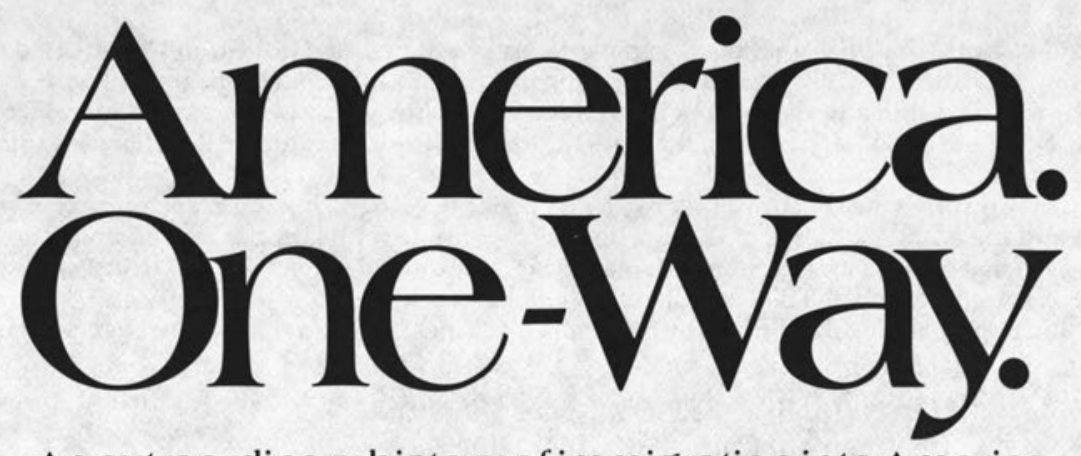

An extraordinary history of immigration into America from 1789 to 1929.

Inspired by the enormous interest of Americans in their immigrant ancestry, Research Publications presents a new, $35 \mathrm{~mm}$ microfilm collection, The Immigrant in America.

Drawn from the archives of the New York Public Library. the Balch Institute for Ethnic Studies Library, the Immigration History Research Center, and the University of Minnesota Libraries, this rare collection covers two major waves of migration in 1820 and the 1880 's when 37 million people came to America. This elusive and fragmented history is now preserved for the study of American immigrants' contributions, as well as their persecution, adjustments and bitter disappointments.

The 6,000 title collection will encompass 10 units of 28 to 45 reels. Standing order price per unit is $\$ 1700$ (15\% below the individual unit price). Prices slightly higher outside U.S. and Canada.

To place an order, or for more information, call or write:

12 Lunar Drive/Drawer AB Woodbridge, CT 06525

(203) 397.2600

TWX: 710-465-6345

FAX: 203-397-3893

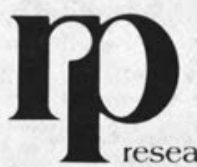

Outside No. and So. America: P.O. Box 45

Reading, RGI 8HF England

TEL: 0734-583247

TELEX: 848336 NADL G

h publications

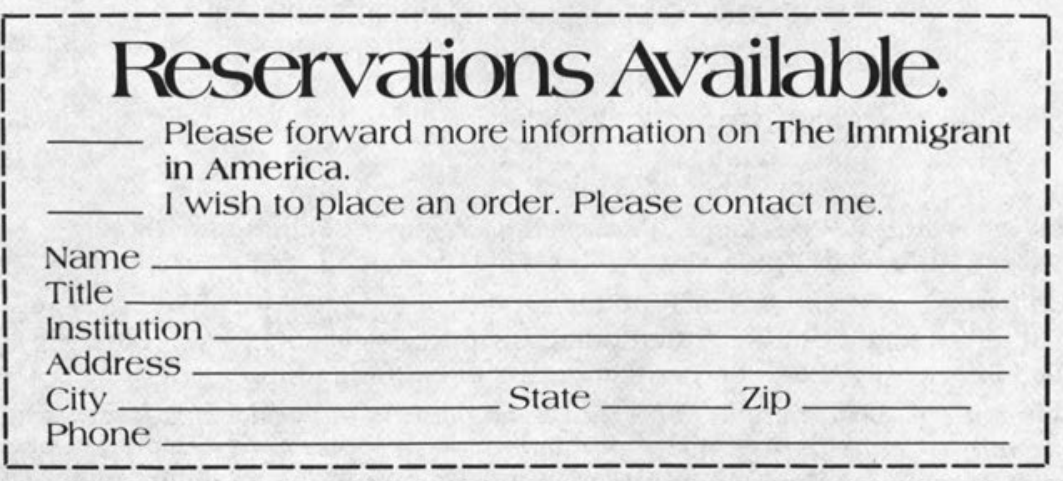


cated this status with some variation as to rank, salary, vacations, and leaves, and 13 reported faculty status but no faculty rank). There is also a growing practice in a number of colleges and universities to raise the Chief Librarian to the level of Dean (New York University, University of Evansville, New Mexico, Southern Illinois and others), thereby emphasizing the importance of their libraries as instructional centers.

The City University has been well served by its policy of recognizing the academic nature of its libraries and the academic status of those who are responsible for its proper functioning. The future promises to make even more strenuous demands on this group of employees and to invest them with more and greater responsibilities than heretofore in the teaching and research process.

-(Document prepared and approved by the Council of Chief Librarians of the City University of New York)

\author{
CATHERINE T. BRODY \\ Chairperson, Council of Chief Librarians \\ New York City Technical College of the City University of New York
}

\title{
IN FORTHCOMING ISSUES OF COLLEGE \& RESEARCH LIBRARIES
}

Financing New Technologies, Replacing Equipment/Furniture, and Renovating Buildings: A Survey

Gary M. Shirk, Yankee Book Peddler

Trash or Treasure? Pop Fiction in Academic and Research Libraries

Robert G. Sewell, University of Illinois at Urbana-Champaign

Manuscripts and Archives/Rare Books: Integration or Separation-a Collection of Papers

Clifton H. Jones, Southern Methodist University; William L. Joyce, New York Pub-

lic Library; Richard C. Berner, University of Washington

A Generic Model of Library Research: Integrating Library Instruction into Process-Oriented Composition Courses

Constance A. Mellon, University of Tennessee at Chattanooga 